УДК 378:004

Вдовичин Тетяна Ярославівна

кандидат педагогічних наук, викладач кафедри інформатики та обчислювальної математики Дрогобицького державного педагогічного університету імені Івана Франка, м. Дрогобич, Україна tetianavdovychyn@gmail.com

\title{
НАВЧАННЯ БАКАЛАВРІВ ІНФОРМАТИКИ З ВИКОРИСТАННЯМ МЕРЕЖНИХ ТЕХНОЛОГІЙ ВІДКРИТИХ СИСТЕМ У ПЕДАГОГІЧНОМУ УНІВЕРСИТЕТІ
}

\begin{abstract}
Анотація. У статті досліджено проблему використання мережних технологій відкритих систем (МТВС) у навчанні майбутніх бакалаврів інформатики. Визначено теоретичні засади використання МТВС у ВНЗ і проаналізовано основні поняття дослідження. Теоретично обгрунтовано і розроблено процедурну модель використання МТВС у навчанні майбутніх бакалаврів інформатики. Визначено критерії, показники і рівні компетентності бакалаврів інформатики щодо використання МТВС і розроблено модель їі формування. Описано основні компоненти методики використання МТВС для майбутніх бакалаврів інформатики й експериментально перевірено іiі ефективність. Експериментальне впровадження результатів дослідження показало, що використання МТВС у навчанні бакалаврів інформатики на основі розробленої методики сприяє формуванню компетентності бакалаврів інформатики щодо використання МТВС.
\end{abstract}

Ключові слова: відкрита освіта; мережні технології відкритих систем; бакалавр інформатики; компетентність щодо використання МТВС.

\section{1. ВСТУП}

Постановка проблеми. Випереджувальний характер системи освіти є надзвичайно важливим чинником конкурентоспроможності випускників вищих навчальних закладів. Адаптація до міжнародних стандартів і вимог спонукають навчальні заклади до апробації й упровадження інноваційних форм, засобів та методик організації навчального процесу.

Нині випускник ВНЗ має швидко адаптуватися у соціально-економічних умовах, отримувати не лише вузькоспеціалізовані, а й фундаментальні знання, сформовані в єдину світоглядну наукову систему. Підготовка студентів в умовах використання інформаційнокомунікаційних технологій (IКТ) допомагає пристосовуватися до швидкозмінних вимог підготовки конкурентоздатних фахівців, упроваджувати інноваційні технології у майбутню діяльність, відповідає стратегічним завданням модернізації системи освіти.

Сучасним інструментом інноваційного розвитку освіти стає ії інформатизація, яка $\epsilon$ базою для розвитку відкритої освіти. Використання принципів такої освіти дає змогу суттєво розширити потенційний простір навчального середовища, забезпечити формування відкритого освітнього простору, що доступний для всіх учасників навчальновиховного процесу.

Відкрита освіта характеризується доступністю й удосконаленням інформаційноресурсного забезпечення методичних систем навчання, розширенням спектру засобів навчання i педагогічних технологій. Відкрите навчальне середовище $\epsilon$ потенційно необмеженим щодо обсягів ресурсів, що можуть бути застосовані в навчально-виховному процесі та чисельності користувачів. Технології відкритої освіти урізноманітнюють процес навчання, підвищують його ефективність, сприяють формуванню особистості, здатної швидко набувати нові та застосовувати раніше набуті для нестандартних ситуацій, творчо і глибоко мислити, раціоналізувати перспективні ідеї та їх реалізацію в майбутній діяльності.

Поява i широке впровадження мережних технологій відкритих систем (МТВС) суттєво впливає на ефективність навчання майбутніх бакалаврів інформатики. Проте існує низка ризиків у використанні МТВС, зокрема, пов'язані із захистом персональних даних, 
можливостями порушення авторського права і плагіату, обмеження морально-етичного і соціального характеру тощо.

Аналіз останніх досліджень і публікацій. Різні аспекти використання ІКТ у навчально-виховному процесі представлено у публікаціях О. М. Алексєєва, В. Ю. Бикова, М. І. Жалдака, Т. І. Коваль, А. М. Коломієць, Н. В. Морзе, В. В. Олійника, В. В. Осадчого, Л. Ф. Панченко, О. Г. Колгатіна, Ю. В. Триуса, С. А. Ракова, Ю. С. Рамського, С. О. Семерікова, О. М. Спіріна та ін.

Проблеми підготовки майбутніх учителів інформатики досліджено у роботах М. І. Жалдака [4], Н. В. Морзе [6], О. М. Спіріна [8], В. П. Олексюка [7] та інших. Ця проблематика висвітлена у працях i закордонних науковців, зокрема, 3 Польщі (Є. Мазинська, Г. Кєдровіч тощо), США (А. Томпсон, Р. Бредлі тощо), Франції (Ж. Арсак), Росії (В. В. Давидов, А. П. Сршов, К. К. Колін, М. П. Лапчик тощо).

Значний внесок у дослідження проблеми використання мережних технологій відкритих систем зроблено В. Ю. Биковим [1], який проаналізував особливості, принципи та технології відкритої освіти. Аспекти формування відкритого освітньо-наукового простору і використання технологій відкритої освіти для навчальних цілей висвітлено у працях М. П. Лещенко, А. В. Яцишин [5], О. В. Овчарук, Л. А. Виноградової, О. С. Висоцької, О. А. Захарової, С. І. Здіорук, А. Ю. Іщенка, М. М. Карпенка, І. А. Колеснікової, А. М. Стрюка, М. В. Храмової, Ж. М. Чупахіної та ін. М. П. Лещенко, Л. І. Тимчук, В.Н.Ковальчук, М. І. Бочаров досліджували морально-етичні аспекти роботи в інформаційному просторі. Актуальними $є$ дослідження провідних фахівців, що працюють у сфері відкритої освіти у США і Європі, зокрема, Торі Іійосі, Віджай Кумар, Стюарт Д. Лі, Трент Бетсон, Енді Лейн, Маршар С. Сміт, Шеріл Р. Річардсон тощо.

Актуальність дослідження: зумовлена його спрямованістю на розв'язання суперечностей між:

- сучасними вимогами до майбутніх бакалаврів інформатики і реальним рівнем їх підготовки, зокрема щодо використання мережних технологій відкритих систем;

- доцільністю використання мережних технологій відкритих систем у навчанні майбутніх бакалаврів інформатики і недостатнім рівнем розробленості методик їх застосування;

- необхідністю формування у майбутніх бакалаврів інформатики компетентності щодо використання мережних технологій відкритих систем і відсутністю ефективних моделей їх реалізації.

Метою статті $\epsilon$ дослідити особливості використання мережних технологій відкритих систем у навчанні майбутніх бакалаврів інформатики.

Організація навчального процесу майбутніх бакалаврів інформатики на основі розробленої методики використання МТВС дасть змогу підвищити результативність процесу навчання, зокрема, сформувати компетентність щодо використання МТВС.

Результати дослідження можуть бути використані бакалаврами інформатики у процесі навчання, під час виконання курсових i дипломних робіт, проходження педагогічної практики (зокрема, для формування системного підходу до безпечної роботи у мережі в учнів загальноосвітніх шкіл); а також для підвищення кваліфікації професорсько-викладацького складу, адміністрації ВНЗ і навчально-допоміжного персоналу щодо використання МТВС; для підвищення кваліфікації вчителів інформатики щодо застосування МТВС.

\section{2. МЕТОДИ ДОСЛІДЖЕННЯ}

Для досягнення мети і реалізації завдань дослідження застосовувався комплекс методів: аналіз педагогічного досвіду щодо впровадження мережних технологій відкритих систем у вищих навчальних закладах; метод концептуально-порівняльного аналізу, за 
допомогою якого змістовно зіставлялися наявні у психолого-педагогічній літературі теоретичні підходи до визначення й обгрунтування шляхів впровадження відкритої освіти в Україні; спостереження - для виявлення особливостей навчання майбутніх бакалаврів інформатики i ïx морально-етичного виховання у відкритому освітньому просторі; анкетування, самооцінювання - для дослідження особистісних переконань студентів, професорсько-викладацького складу, адміністрації ВН3 i навчально-допоміжного персоналу щодо використання мережних технологій відкритих систем та щодо адекватного сприйняття й оцінки інформації, ідентифікації загроз на основі моральноетичних і культурних цінностей; моделювання - для розробки моделей використання мережних технологій відкритих систем у навчанні бакалаврів інформатики та формування їх компетентності; методи математичної статистики для опрацювання результатів педагогічного експерименту.

\section{3. РЕЗУЛЬТАТИ ДОСЛІДЖЕННЯ}

В умовах інформатизації і модернізації системи освіти України відбувається перетворення традиційного навчального процесу, удосконалюються відкриті форми освітньої діяльності, а розвиток глобальних мереж і єдиного інформаційного простору сприяє формуванню на світовому ринку освітніх послуг із застосуванням мережних технологій відкритих систем.

Процеси демократизації, гуманізації і глобалізації, що мають місце у світовому співтоваристві і в свідомості людей, спричинили виникнення такої категорії як «відкритість». Це стало підгрунтям для становлення нової риси освіти, а саме «відкритості» як гнучкості, демократичності, індивідуальності в отриманні знань. Вимоги загального відкритого доступу до освіти, діалогу з міжнародним співтовариством і низка інших чинників заклали фундамент для ідей відкритої освіти. Відкрита освіта відображає головну складову цивілізованого соціуму - гуманістичну спрямованість, інтеграцію, ефективність, доступність в отриманні знань, безперервність навчання протягом життя, $\epsilon$ потребою часу і умовою суспільного розвитку. Вона буде розвиватися й надалі, вбираючи в себе досвід і розробки. До навчання у відкритому освітньому середовищі залучаються всі охочі: не обмежується вік, соціально-професійний статус, громадянство, територія проживання вступника. Така нова освітня парадигма вимагає необхідності реагування на потреби людини, на суспільні виклики, на об'єктивні процеси їх розвитку та спрямована на необхідність створення умов для рівного доступу до якісної освіти для всіх.

Аналіз зарубіжного досвіду дав змогу визначити хронологію становлення відкритої освіти у світі. Освітня система України також слідує принципам відкритої освіти як перспективному шляху, як потенціалу для забезпечення випереджувального розвитку національної системи освіти. Проаналізувавши низку державних документів і наукових публікацій, охарактеризовано етапи становлення відкритої освіти в Україні:

I eman - do 2000 p. (головним напрямом стає інформатизація освіти);

II eman - 2000-2009 pp. (впровадження IКТ, розвиток інформаційного суспільства, перехід на програмне забезпечення з відкритим кодом);

III eman - 2010-2011 pp. (забезпечення відкритого доступу до освітніх і навчальних матеріалів, розширення можливостей для колективної роботи в рамках навчального процесу, зростання ефективності управління системою освіти на всіх рівнях);

IV eman - 2012-2014 pp. (створення інформаційної системи підтримки освітнього процесу, розвиток мережі електронних бібліотек, створення системи дистанційного навчання, доступ навчальних закладів до світових інформаційних ресурсів);

$V$ eman - 32014 p. по теперішній час (доступність, мобільність, відкритість формування структури й обсягу освітньої і професійної підготовки фахівців 3 вищою освітою тощо). 
Досліджено понятійний набір таких категорій: «відкрита освіта», «відкрите навчання», «відкрите навчальне середовище», «відкрита інформаційна система», «відкритий освітній простір», «мережні технології відкритих систем» тощо, встановлено співвідношення і взаємозв'язки між ними.

Зокрема, публікації вітчизняних і зарубіжних вчених (А. А. Андреєва, М. В. Андреєва, В. Ю. Бикова, О. Є. Висоцької, О. А. Захарової, А. М. Лобок, В. М. Лупанова, О. В. Овчарук, В. І. Соколова, Р. С. Гуревича та ін.) дали змогу визначити тлумачення поняття «відкрита освіта» як змістової складової глобальної освіти, пов'язаної в першу чергу 3 побудовою мережних форм освітнього простору, застосуванням IKT, дистанційних форм навчання, опануванням відповідних вмінь, навичок та компетентності.

«Електронна відкрита система»- це система, що функціонує і моделюється у відкритому навчальному середовищі, яке створює потенційні умови для суттєвого поліпшення інформаційно-ресурсного забезпечення методичних систем навчання, розширення спектру засобів і педагогічних технологій, що можуть бути застосовані у навчально-виховному процесі.

Досліджуючи мережні технології відкритих систем, розглянуто системи, що функціонують на відкритих стандартах чи вільному програмному забезпеченні, й обрано ті системи чи їхні окремі сервіси, застосування яких вважаємо доцільним і актуальним для інформатизації ВН3, а саме, з метою використання їх у навчанні майбутніх бакалаврів інформатики.

Під «мережними технологіями відкритих систем» освітнього призначення розуміємо такі програмні засоби електронних відкритих систем, за допомогою яких здійснюється:

- персональне і колективне використання цих систем або їх сервісів для освітніх цілей;

- мережна взаємодія користувачів з метою забезпечення навчальної комунікації та спільної навчальної діяльності;

- інформаційна підтримка навчально-виховного процесу у мережному середовищі тощо.

У дослідженні до мережних технологій відкритих систем віднесено:

- освітні та наукові інформаційні мережі;

- електронні бібліотеки;

- автоматизовані системи перевірки унікальності текстів;

- електронні соціальні мережі;

- технології дистанційного і мобільного навчання;

- технології автоматизації досліджень і розробок тощо.

Для добору МТВС, які доцільно використовувати для навчання майбутніх бакалаврів інформатики, варто застосовувати певні критеріï, а саме: доступність, технічні характеристики, функціональні можливості, ергономічність, вибір рівня складності, інтуїтивний і зрозумілий інтерфейс, наявність зворотного зв'язку, перспективи розвитку, підтримки й інтеграції, мобільність, захист персональних даних, забезпечення академічної доброчесності, дотримання авторських прав, врахування морально-етичних норм.

Досліджуючи стан підготовки бакалаврів інформатики, було проаналізовано нормативно-правову базу, навчальні плани, розподіл дисциплін за циклами та зосереджено увагу на фундаментальних дисциплінах. Обгрунтовано, що впровадження МТВС розширює простір навчального середовища, ставить нові вимоги до процесу набуття студентами знань, умінь та навичок, враховує індивідуальні потреби щодо забезпечення особистісного розвитку.

Визначено, що процес навчання із застосуванням технологій відкритих педагогічних систем $є$ інтерактивним і доступним для всіх. Застосування МТВС у ВНЗ сприятиме формуванню єдиного інформаційного освітнього середовища, покращенню взаємодії між 
викладачами і студентами, що дозволяє моделювати й конструювати дане середовище відповідно до різних потреб соціальних груп.

Також варто наголосити на формуванні умінь щодо безпечного використання МТВС для неперервного особистісного розвитку. Важливо для майбутніх бакалаврів інформатики поєднувати розвиток професійних навичок 3 умінням протистояти негативним інформаційним впливам i маніпуляціям. Одним 3 основних завдань уи використанні МТВС вважаємо формування морально-етичних навичок комунікації у сучасному мережному суспільстві.

Використання МТВС буде найбільш ефективним за умови формування у студентів морально-етичних навичок мережної комунікації в сучасному інформаційному середовищі (здатності протистояти агресивному медіа середовищу і критично оцінювати електронні інформаційні ресурси, умінню безпечно використовувати персональні дані, відомості, навички етичного мережного спілкування тощо).

Встановлено, що МТВС покращують співпрацю всіх учасників навчально-виховного процесу. Важливою умовою використання МТВС для навчання майбутніх бакалаврів інформатики вважаємо підвищення кваліфікації професорсько-викладацького складу й адміністрації ВНЗ.

Для визначення сучасного стану використання МТВС у вітчизняних ВНЗ було організовано і проведено аналітико-пошукове дослідження, що передбачало анкетування й опитування студентів, професорсько-викладацького складу, адміністрації ВНЗ та навчально-допоміжного персоналу. Результати опитування дали підстави зробити такі висновки: переважна більшість учасників (студенти - 54 \%, професорсько-викладацький склад - 73\%, адміністрація ВНЗ та навчально-допоміжний персонал - 65 \%) вважає, що застосовувати МТВС у ВНЗ є доцільно і своєчасно (рис. 1). Це свідчить про усвідомлення учасниками навчально-виховного процесу значущості відкритої освіти у фундаментальній, науковій підготовці фахівців, інтелектуальному розвитку особистості, модернізації процесу навчання у ВН3.

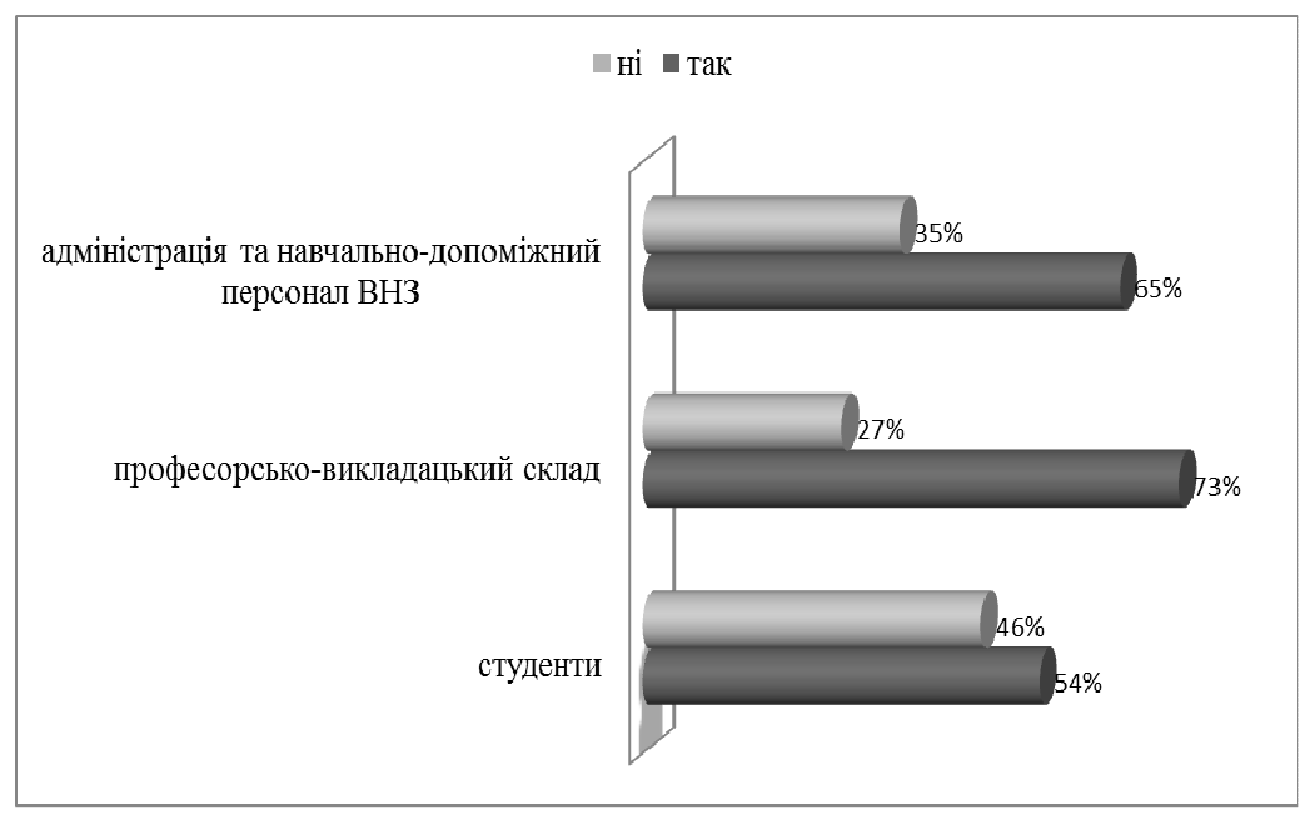

Рис. 1. Розподіл відповідей учасників щуодо доцільності використання МТВС

Розроблено процедурну модель використання $M T B C$ у навчанні майбутніх бакалаврів інформатики (рис. 2), яка передбачає підготовчий, мотиваційний, організаційний, діяльнісний етапи. Мета моделі - впровадження МТВС для удосконалення процесу навчання майбутніх бакалаврів інформатики. Вона має змістовий і технологічний блоки і передбачає рівні впровадження. До реалізації моделі залучені: бакалаври інформатики, 
професорсько-викладацький склад, адміністрація ВНЗ та навчально-допоміжний персонал.

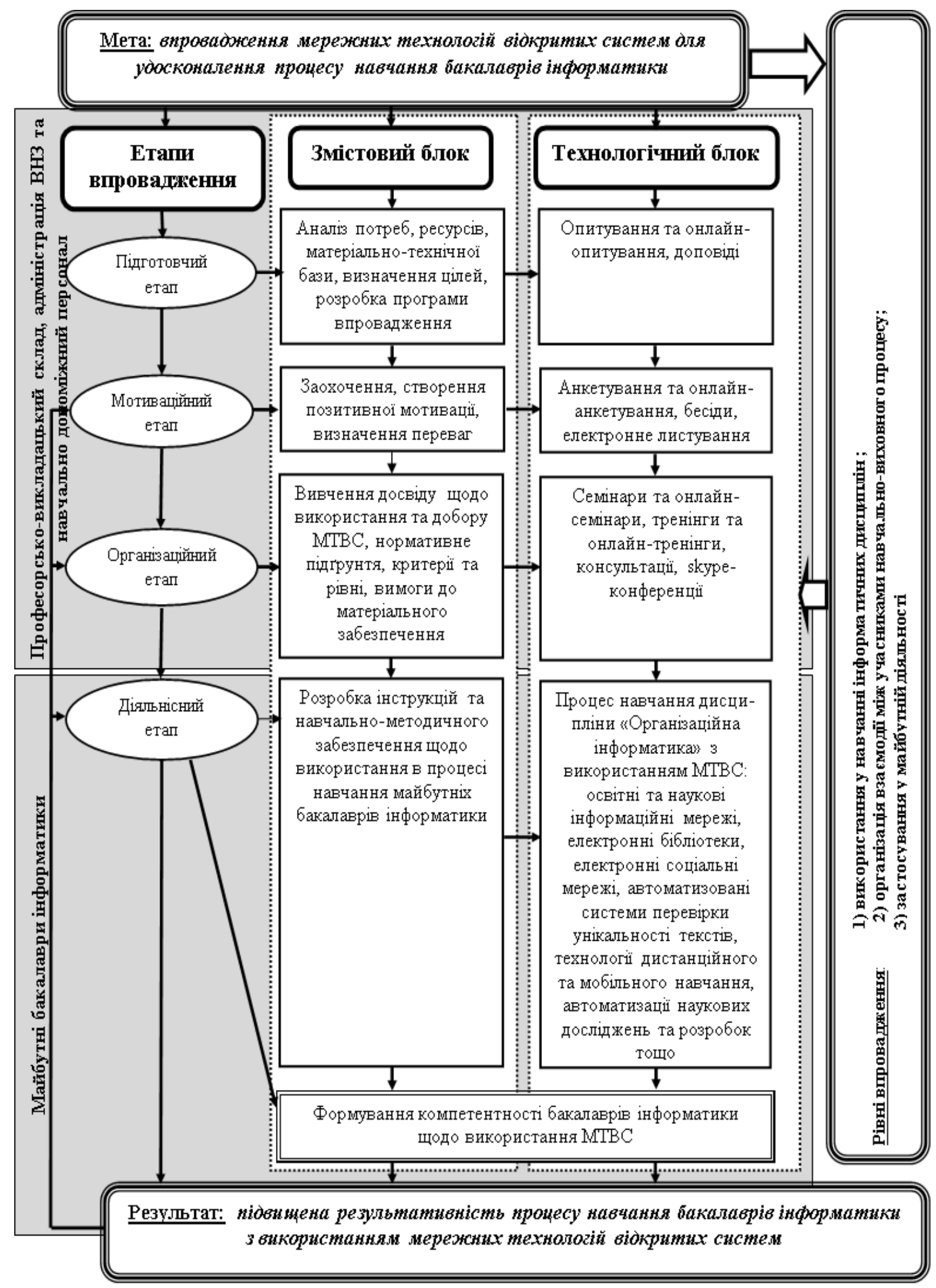

Рис. 2. Прочеедрна модель використання МТВС у навчанні майбутніх бакалаврів інформатики 


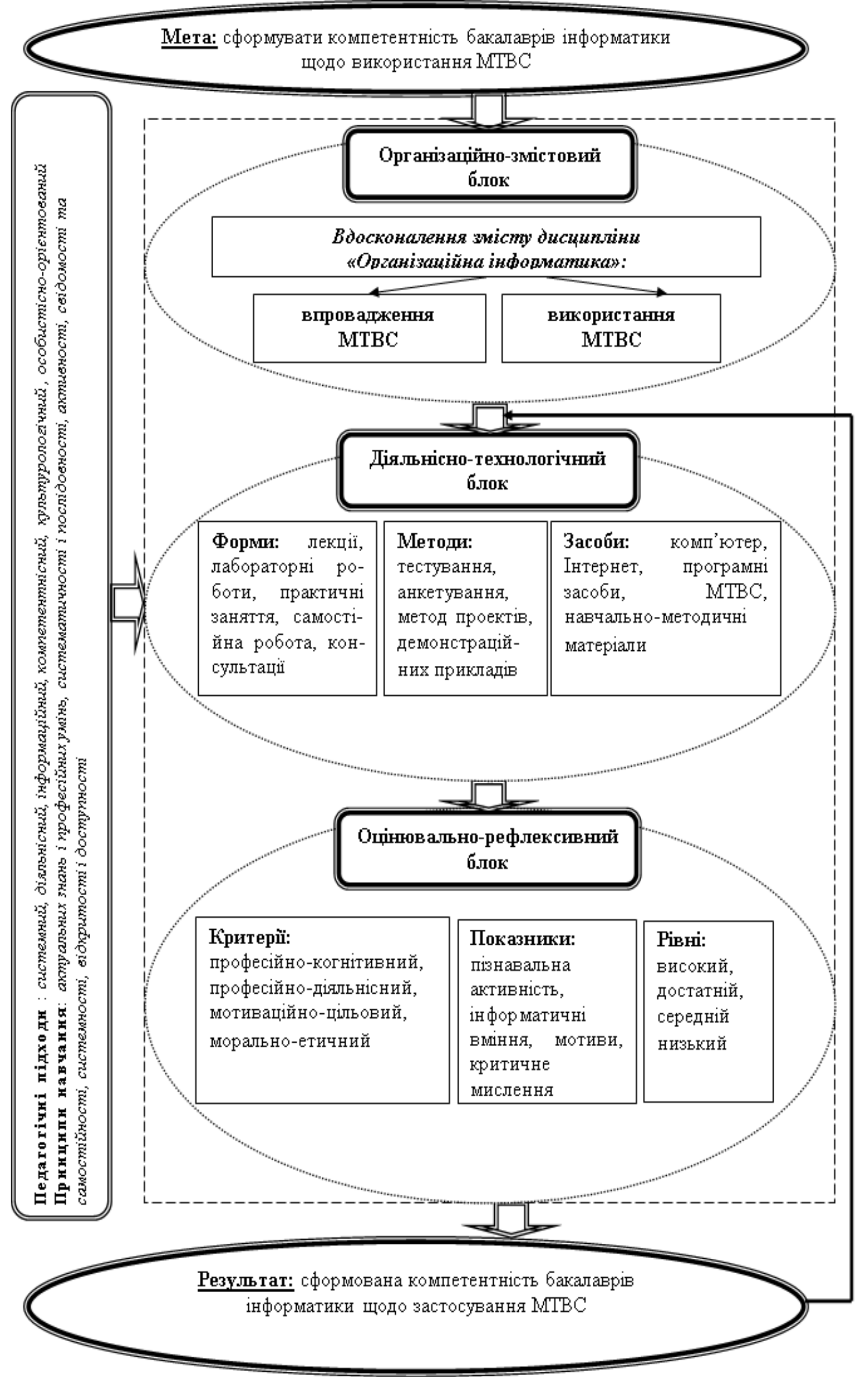

Рис. 3. Модель формування компетентності бакалаврів інформатики щэодо використання МТВС 
На основі аналізу наукових і методичних джерел було розроблено модель формування компетентності бакалаврів інформатики щзодо використання МТВС (рис. 3). Модель складається 3 мети, трьох блоків, очікуваного результату і враховує педагогічні підходи i принципи навчання. В організаційно-змістовому блоці передбачається оновлення змісту навчальної дисципліни «Організаційна інформатика» через упровадження МТВС, у діяльнісно-технологічному - удосконалення форм організації, методів та засобів навчання, зокрема МТВС, що доцільно застосовувати у навчанні майбутніх бакалаврів інформатики, в оцінювально-рефлексивному - визначення сформованості компетентності майбутніх бакалаврів інформатики щодо використання MTBC.

Визначено критерії (професійно-когнітивний, професійно-діяльнісний, мотиваційноцільовий, морально-етичний), за якими доцільно здійснювати оцінювання сформованості компетентності бакалаврів інформатики щодо використання МТВС за рівнями (низький, середній, достатній, високий). Критеріям компетентності відповідають певні показники, а саме: пізнавальна активність, інформатичні вміння, мотиви і критичне мислення.

Доцільно навчати майбутніх бакалаврів інформатики за розробленою методикою використання МТВС.

Мета навчання полягає у забезпеченні використання МТВС у процесі підготовки бакалаврів інформатики і формуванні у них відповідної компетентності.

3міст навчання - удосконалення інформатичних дисциплін з використанням МТВС (на прикладі змістового наповнення навчальної дисципліни «Організаційна інформатика»).

Форми організації навчання. Опанування навчальним курсом здійснюється під час лекційних, лабораторних, практичних занять, самостійної роботи студентів. Лекційний курс $з$ навчальної дисципліни «Організаційна інформатика» передбачає ознайомлення студентів з ІКТ, особливостями і ризиками відкритої освіти, використанням МТВС у процесі навчання. На лабораторних заняттях студенти мають змогу удосконалити знання щодо використання прикладного програмного забезпечення, оптимізації роботи 3 документами, електронними таблицями, презентаціями тощо. Вважаємо доцільним на лабораторних заняттях наголошувати студентам на коректній поведінці під час використання МТВС (зокрема, наприклад, пропонуємо створити студентський проект на тему «Обережно, Інтернет!»).

Під час практичних занять студенти матимуть змогу ознайомитися з МТВС, а саме 3 технологіями дистанційного навчання (на прикладі Moodle), автоматизації досліджень i розробок (на прикладі Google Drive), підтримки взаємозв’язку з використання мобільних пристроїв (на прикладі Google Calendar), електронними соціальними мережами (на прикладі Facebook), електронними бібліотеками (на прикладі електронної бібліотеки НАПН України), освітніми (на прикладі Wolfram|Alpha) та науково-популярними (на прикладі Wikipedia) інформаційними мережами тощо.

Самостійна робота студентів передбачає дослідження МТВС, а саме браузерів, пошукових і геоінформаційних сервісів, засобів інтернет-телефонії (на прикладі Skype), сервісів для розміщення відеофайлів (на прикладі YouTube), онлайн-перекладачів, електронних підручників у відкритому доступі. Студентам пропонується самостійно розробити «Кодекс безпечного використання МТВС» 3 подальшим його обговоренням на аудиторних заняттях.

Серед засобів навчання важливу роль відіграє не тільки матеріально-технічне забезпечення, а й якісні навчально-методичні матеріали.

Розглянуті компоненти методики використання МТВС у навчанні майбутніх бакалаврів інформатики й експериментальна перевірка дають підстави стверджувати про можливість і педагогічну доцільність ii застосування для формування компетентності студентів. 
У педагогічному експерименті взяло участь 390 учасників: на констатувальному етапі дослідження - 150 учасників (115 студентів, 20 викладачів, 15 представників адміністрації ВН3 та навчально-допоміжного персоналу); в експериментальному навчанні взяло участь 240 студентів Дрогобицького державного педагогічного університету імені Івана Франка (контрольна група - 112 й експериментальна група - 128).

3 метою апробації розробленої методики використання МТВС у навчанні майбутніх бакалаврів інформатики був проведений формувальний етап педагогічного експерименту. Навчання студентів експериментальних груп проводилось згідно 3 розробленою методикою використання МТВС. Було зафіксовано позитивну динаміку формування компетентності бакалаврів інформатики щодо використання МТВС в експериментальних групах (рис. 4).
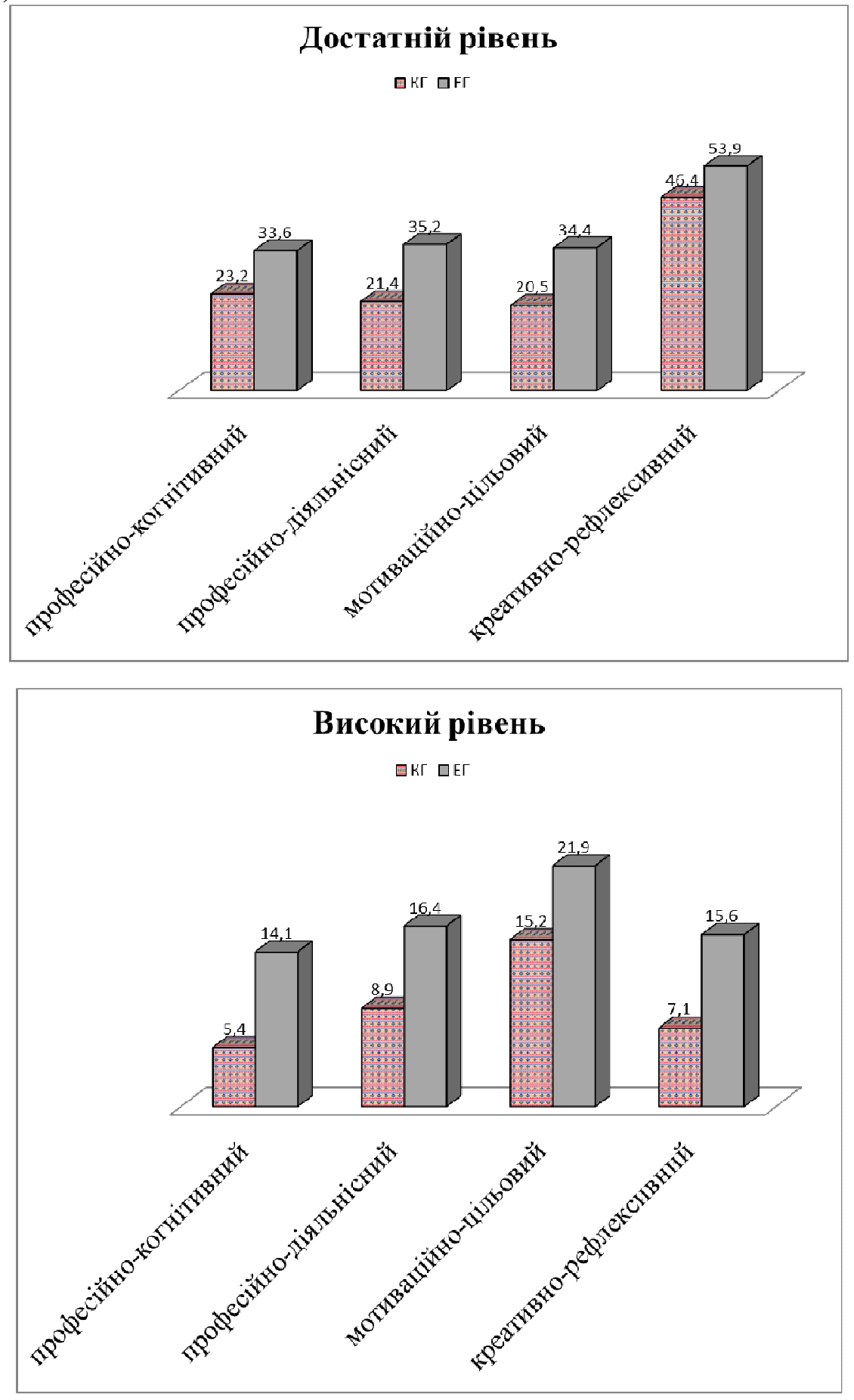

Рис. 4. Динаміка зміни достатнього і високого рівнів сформованості компетентності бакалаврів інформатики щзодо використання МТВС за критеріями 
Для перевірки статистичних відмінностей студентів контрольних i експериментальних груп було обрано критерій Пірсона $\left(T_{\kappa p}=7,815\right)$. Було виявлено відмінності розподілу рівня сформованості компетентності бакалаврів інформатики щодо використання МТВС (таблиця 1).

Таблиця

Динаміка рівнів сформованості компетентності бакалаврів інформатики щодо використання МТВС за критеріями

\begin{tabular}{|c|c|c|c|c|c|c|}
\hline \multirow{2}{*}{ Критерії } & \multirow{2}{*}{ Групи } & \multicolumn{4}{|c|}{ Рівні } & \multirow{2}{*}{$\mathbf{T}_{\text {екс }}$} \\
\hline & & низький & середній & достатній & високий & \\
\hline \multirow{2}{*}{$\begin{array}{l}\text { Професійно- } \\
\text { когнітивний }\end{array}$} & $\mathrm{E} \Gamma$ & 12 & 55 & 43 & 18 & \multirow[b]{2}{*}{10,788} \\
\hline & КГ & 18 & 62 & 26 & 6 & \\
\hline \multirow{2}{*}{$\begin{array}{l}\text { Профессійно- } \\
\text { діяльнісний }\end{array}$} & $\mathrm{E} \Gamma$ & 12 & 50 & 45 & 21 & \multirow[b]{2}{*}{11,873} \\
\hline & КГ & 20 & 58 & 24 & 10 & \\
\hline \multirow{2}{*}{$\begin{array}{l}\text { Мотивачійно- } \\
\text { иілльовий }\end{array}$} & $\mathrm{E} \Gamma$ & 17 & 39 & 44 & 28 & \multirow[b]{2}{*}{10,519} \\
\hline & КГ & 25 & 47 & 23 & 17 & \\
\hline \multirow{2}{*}{$\begin{array}{l}\text { Морально- } \\
\text { етичний }\end{array}$} & $\mathrm{E} \Gamma$ & 4 & 35 & 69 & 20 & \multirow[b]{2}{*}{10,846} \\
\hline & КГ & 12 & 40 & 52 & 8 & \\
\hline
\end{tabular}

Отже, педагогічний експеримент підтвердив ефективність запропонованої методики.

Для підвищення кваліфікації професорсько-викладацького складу, адміністрації ВНЗ та навчально-допоміжного персоналу ВНЗ було організовано і проведено низку семінарів. Зокрема, МТВС були впроваджені в роботу кафедри інформатики та обчислювальної математики Дрогобицького державного педагогічного університету імені Івана Франка.

\section{4. ВИСНОВКИ ТА ПЕРСПЕКТИВИ ПОДАЛЬШИХ ДОСЛІДЖЕНЬ}

На підставі отриманих результатів дослідження обгрунтовано, що використання МТВС у ВНЗ є доцільними й актуальними. Охарактеризовано основні терміни і поняття дослідження і встановлено взаємозв'язки між ними. Наголошено, що важливим завданням використання МТВС є формування морально-етичних навичок комунікації у сучасному мережному суспільстві. Визначено критерії і здійснено добір МТВС (освітні і наукові інформаційні мережі, електронні бібліотеки, автоматизовані системи перевірки унікальності текстів, електронні соціальні мережі, технології дистанційного і мобільного навчання, автоматизації досліджень і розробок тощо), які доцільно використовувати для навчання майбутніх бакалаврів інформатики.

Процедурна модель використання МТВС у навчанні майбутніх бакалаврів інформатики слугує підгрунтям для розробки методики використання МТВС і включає: мету, змістовий та технологічний блоки, етапи впровадження і результат. Реалізація запропонованої моделі передбачає підготовчий, організаційний, мотиваційний, діяльнісний етапи впровадження МТВС для адміністрації ВН3 і навчально-допоміжного персоналу, професорсько-викладацького складу і студентів. Необхідним складником процедурної моделі $є$ формування компетентності бакалаврів інформатики щодо 
використання МТВС. Розроблена модель може бути впроваджена у ВНЗ для навчання бакалаврів інформатики.

Формування компетентності майбутніх бакалаврів інформатики щодо використання МТВС доцільно здійснювати на основі окремо розробленої моделі з урахуванням визначених критеріїв, показників і рівнів. Така модель базується на педагогічних підходах (системний, діяльнісний, інформаційний, компетентісний, особистісно-орієнтований, культурологічний) i включає три взаємопов'язані блоки: організаційно-змістовий (передбачає вдосконалення змісту навчальної дисципліни «Організаційна інформатика» через впровадження МТВС), діяльнісно-технологічний (вміщує організаційні форми, методи та засоби навчання, зокрема МТВС, що доцільно застосовувати у навчанні майбутніх бакалаврів інформатики), оцінювально-рефлексивний (передбачає визначення сформованості компетентності майбутніх бакалаврів інформатики щодо використання МТВС у професійній діяльності за критеріями: професійно-когнітивний, професійнодіяльнісний, мотиваційно-цільовий, морально-етичний відповідно до рівнів: низький, середній, достатній, високий).

Упровадження методики використання МТВС у навчанні майбутніх бакалаврів інформатики підтвердило іiі ефективність. Розроблена методика є педагогічно доцільною відповідно до позитивної динаміки сформованості компетентності бакалаврів інформатики щодо використання МТВС. Застосування методики дасть змогу урізноманітнити навчальний процес у ВНЗ включенням певних засобів, зокрема, електронних соціальних мереж, електронних бібліотек, технологій дистанційного i мобільного навчання тощо.

Проведене дослідження не вичерпує всіх аспектів означеної проблеми, подальшого вивчення потребують питання: використання МТВС у навчанні студентів інших напрямів підготовки, зокрема у викладанні інформатичних дисциплін, мінімізації небезпечного впливу МТВС на користувача; для підвищення кваліфікації професорсько-викладацького і навчально-допоміжного персоналу ВНЗ щодо впровадження МТВС.

\section{СПИСОК ВИКОРИСТАНИХ ДЖЕРЕЛ}

1. Биков В. Ю. Моделі організаційних систем відкритої освіти: монографія / В. Ю. Биков - К.: Атіка, 2009. $-684 \mathrm{c}$.

2. Вдовичин Т.Я. Використання мережних технологій відкритих систем у навчанні майбутніх бакалаврів інформатики: дис. канд. пед. наук: 13.00.10 / Вдовичин Тетяна Ярославівна. - К., 2017. - 290 с.

3. Вдовичин Т. Я. Використання мережних технологій відкритих систем у навчанні бакалаврів інформатики: загальні висновки / Т. Я. Вдовичин // Інформаційні технології в освіті. - 2016. - Вип. 27. - Режим доступу : http://ite.kspu.edu/webfm_send/890 - C. 167-185.

4. Жалдак М. І. Про деякі методичні аспекти навчання інформатики в школі та педагогічному університеті // Наукові записки Тернопільського національного університету ім.В.Гнатюка. Серія: Педагогіка, 2005. - № 6. - С. 17-24.

5. Лещенко М. П. Відкрита освіта в категоріальному полі вітчизняних та зарубіжних вчених [Електронний ресурс] / Лещенко М. П., Яцишин А. В. / Інформаційні технології і засоби навчання. 2014. - № 1. - Режим доступу: http://journal.iitta.gov.ua/index.php/ittl/article/view/985\#.U3s6sdJ_tgs.

6. Морзе Н. В. Система методичної підготовки майбутніх вчителів інформатики в педагогічних університетах: дис... д-ра пед. наук: 13.00.02 / Н. В. Морзе / Національний педагогічний ун-т ім. М.П.Драгоманова. - К., 2003. - 605 с.

7. Олексюк В. П. Застосування віртуальних хмарних лабораторій у процесі підготовки майбутніх учителів інформатики / В. П. Олексюк // Науковий часопис НПУ ім. М. П. Драгоманова. Сер. № 2. Комп'ютерно-орієнтовані системи навчання: [зб. наук. праць]. № 15 (22) / Редрада. - К. : НПУ ім. М. П. Драгоманова, 2015.- С. 76-81

8. Спірін О. М. Теоретичні та методичні засади професійної підготовки майбутніх вчителів інформатики за кредитно-модульною системо: онографія / О. М. Спірін / За наук. ред. акад. М. І. Жалдака. Житомир: Вид-во ЖДУ ім. І. Франка, 2007. - 300 с. 


\title{
ОБУЧЕНИЕ БАКАЛАВРОВ ИНФОРМАТИКИ С ИСПОЛЬЗОВАНИЕМ СЕТЕВЫХ ТЕХНОЛОГИЙ ОТКРЫТЫХ СИСТЕМ В ПЕДАГОГИЧЕСКОМ УНИВЕРСИТЕТЕ
}

\section{Вдовичин Татьяна Ярославовна}

кандидат педагогических наук, преподаватель кафедры информатики и вычислительной математики Дрогобычского государственного педагогического университета имени Ивана Франко,

г. Дрогобыч, Украина

tetianavdovychyn@gmail.com

\begin{abstract}
Аннотация. В статье исследована проблема использования сетевых технологий открытых систем (СТОС) в обучении будущих бакалавров информатики. Определены теоретические основы использования СТОС в вузах и проанализированы основные понятия исследования. Теоретически обоснованы и разработаны процедурную модель использования СТОС в обучении будущих бакалавров информатики. Определены критерии, показатели и уровни компетентности бакалавров информатики по использованию СТОС и разработана модель ее формирования. Описаны основные компоненты методики использования СТОС для будущих бакалавров информатики и экспериментально проверена еe эффективность. Экспериментальное внедрение результатов исследования показал, что использование СТОС в обучении бакалавров информатики на основе разработанной методики способствует формированию компетентности бакалавров информатики по использованию СТОС.
\end{abstract}

Ключевые слова: открытое образование; сетевые технологии открытых систем; бакалавр информатики; компетентность по использованию СТОС.

\section{TRAINING OF BACHELORS OF COMPUTER SCIENCE USING OPEN SYSTEMS NETWORK TECHNOLOGIES AT PEDAGOGICAL UNIVERSITIES}

\section{Tatiana Ya. Vdovychyn}

$\mathrm{PhD}$ (Pedagogical Sciences), lecturer in Computer Science and Computational Mathematics

Drohobych State Pedagogical University named after Ivan Franko, Drohobych, Ukraine

tetianavdovychyn@gmail.com

\begin{abstract}
The article studies the problem of the use of open systems network technologies (OSNTs) in training of future bachelors of computer science. The theoretical principles of the use of OSNTs in higher educational institutions are defined and the basic concepts of the study are analyzed. The procedural model of the use of OSNTs in training of future bachelors of computer science is theoretically grounded and developed. The criteria, indicators and levels of competence of bachelors of computer science concerning the use of OSNTs are defined and the model of its formation is developed. The main components of OSNTs using technique for future bachelors of computer science are described and its effectiveness is experimentally verified. The experimental implementation of the study results showed that the use of OSNTs in training of bachelors of computer science based on the developed technique promotes the competence formation of bachelors of computer science concerning the use of OSNTs.
\end{abstract}

Keywords: open education; open systems network technologies; bachelor of computer science; competence on using OSNTs.

\section{REFERENCES (TRANSLATED AND TRANSLITERATED)}

1. Bykov V. Yu. Models of the open education organizational systems: Monograph.- K.: Atika, 2008- 684 p.: ill. (in Ukrainian).

2. Vdovychyn T.J. The use of network technologies of open systems in the training of future bachelors of computer science: dys. kand. ped. nauk: 13.00.10 / Vdovychyn Tetyana Yaroslavivna. - K., 2017. - 290 p. (in Ukrainian).

3. Vdovychyn T.J. The use of network technologies of open systems in the training of future bachelors of computer science: zahal'ni vysnovky [online] / T.J. Vdovychyn // Information Technologies in Education. 2016. - Vyp. 27. - Available from: http://ite.kspu.edu/webfm_send/890 - P. 167-185. (in Ukrainian). 
4. Zhaldak M.I. Some methodological aspects of teaching science in school and Pedagogical University / M.I. Zhaldak // Scientific notes Ternopil National University im.V.Hnatyuka. Series: Pedagogy, 2005. - № 6. - P. 17-24. (in Ukrainian).

5. Maria P. Leshchenko. Category of "open education" in the works of native and foreign scientists [online] /
Maria
P.
Leshchenko,
Anna
$\mathrm{V}$.
Yatsishin

Information Technologies and Learning Tools. - 2014. - №1. - Available from: http://journal.iitta.gov.ua/index.php/itlt/article/view/985\#.U3s6sdJ_tgs (in Ukrainian).

6. Morse N.V. System of methodical preparation of future teachers of computer science in pedagogical universities: Dis ... Dr. ped. Sciences: 13.00 .02 / N.V. Morse / National Pedagogical University named after. Dragomanov. - K., 2003. - 605 p. (in Ukrainian).

7. Oleksyuk V.P. The use of virtual laboratory cloud in the preparation of future teachers Informatics / V.P. Oleksyuk // Naukovyi chasopys NPU imeni M. P. Drahomanova. Seriia 2. Kompiuterno-oriientovani systemy navchannia : zb. nauk. pr. - K. : NPU im. M. P. Drahomanova, 2015. - No 15 (22). - P. 76-81. (in Ukrainian)

8. Spirin O.M. Theoretical and methodological foundations of training future teachers for science credit system: Monograph / O.M. Spirin / For science. Ed. Acad. MI Zhaldak. - Exactly: Izd hoped to them. Franko, 2007. 300 p. (in Ukrainian).

\section{(cc) EY-NC-SA}

This work is licensed under Creative Commons Attribution-NonCommercial-ShareAlike 4.0 International License. 